\title{
Ekonomik Kriz Dönemlerinde İşletmelerin Muhasebeye Karşı Tutumlarındaki Değişikliklerin Belirlenmesine Yönelik Bir Araştırma
}

\author{
Osman TUĞAY* \\ Hüseyin DALĞAR ** \\ Ömer TEKŞEN***
}

\section{$\ddot{O Z Z T T}$}

Ekonomik kriz dönemleri işletmelerin en kırılgan olduklarl dönemlerdir. Bu nedenle işletme yöneticilerinin kararlarında çok daha dikkatli ve bilinçli davranmaları gerekmektedir. Bilinçli karar verme ise ancak işletmenin finansal verilerini iyi okumakla mümkün olabilir. Dolayısıyla işletmelerin ekonomik kriz. dönemlerinde muhasebeye ve muhasebenin ürettiği verilere her zamankinden daha fazla önem vermeleri beklenen bir durumdur.

Bu bağlamda çalışmada ekonomik kriz dönemlerinde işletmelerin muhasebeye karşı tutumlarındaki değişiklikleri tespit etmek amaçlanmaktadır. Bu amaç doğrultusunda bu tutum değişikliğini en iyi gözlemleme imkanına sahip olan muhasebecilerle anket yapılmıştır. Yapılan analizler sonucunda, işletmelerin kriz. dönemlerinde muhasebeye karşı tutumlarında açıkça bir değişiklik meydana geldiği, ancak bu değişikliğin krizi daha iyi yönetebilmek ve karar desteği săglamak gibi amaçlardan çok, devlete karşı yasal sorumlulukları aksatmadan yerine getirebilme yönünde ortaya çıktı̆̆ tespit edilmiştir.

Anahtar Kelimeler: Ekonomik Kriz, Muhasebeye Karşı Tutum.

JEL Sinıflandırmasi: M41, M49.

\section{A Study To Determine The Changes On Businesses' Attitudes Towards Accounting} In Economilc Crisis Periods

\section{ABSTRACT}

Economic crisis periods are the most fragile times for the businesses. Therefore, business administrators have to act more attentive and conscious in their decisions. Making conscious decisions is only possible through reading financial data elaborately. For this reason it is an expected situation in the crisis periods that businesses value accounting and the data created by its applications.

In this context this study aims to determine the changes on businesses' attitudes towards accounting in economic crisis periods. To realize this a questionnaire is made to the accountants who would observe such an attitude change better. The analysis show that there is a clear change on the attitudes businesses hold towards the accounting however this change is to meet the legal obligations to the state without disrupting rather than managing the crisis better or providing decision support.

Keywords: Economic Crisis, Attitudes Towards Accounting.

Jel Classification: M41, M49.

\footnotetext{
Yrd. Doç. Dr. Osman Tuğay, Mehmet Akif Ersoy Üniversitesi, İktisadi ve İdari Bilimler Fakültesi, otugay@mehmetakif.edu.tr

** Doç. Dr. Hüseyin Dalğar, Mehmet Akif Ersoy Üniversitesi, İktisadi ve İdari Bilimler Fakültesi, hdalgar@mehmetakif.edu.tr .

*** Doç. Dr. Ömer Tekşen, Mehmet Akif Ersoy Üniversitesi, İktisadi ve İdari Bilimler Fakültesi, omerteksen@mehmetakif.edu.tr
} 


\section{GíRiş̧}

Ekonomik krizler makro anlamda tüm ülke ekonomisinde, mikro anlamda ise işletmelerin finansal yapılarında önemli etkiler meydana getirmektedir. İşletmelerin finansal yapılarında meydana gelen olumsuz etkiler nedeniyle işletme yöneticilerinin bu dönemde her zamankinden daha dikkatli ve rasyonel karar vermeleri gerekmektedir. Bu dönemlerde adeta fırtınalı bir denizden gemisini en az hasarla kurtarma telaşında olan işletme yöneticilerinin başarılı bir kriz yönetimi gerçekleştirebilmeleri için attıkları adımları ve aldıkları kararları güvenilir verilere dayandırmaları gerekmektedir. İşletmelerin güvenilir finansal verileri ise muhasebe fonksiyonu tarafından üretilmektedir.

Tüm işletme faaliyetlerini belirli bir sistematik içerisinde kayıt edip raporlayan muhasebe fonksiyonunun önemi kriz dönemlerinde daha da artmaktadır. Muhasebe fonksiyonunun artan bu önemine paralel şekilde işletmelerin, muhasebeye karşı tutamlarında da bir değişiklik meydana gelmesi, değişik amaç ve beklentilerle muhasebeye ve muhasebe verilerine olan ilgilerinin artması beklenen bir durumdur.

$\mathrm{Bu}$ bağlamda çalışmada, öncelikle ekonomik kriz dönemlerinde işletmelerin muhasebeye yönelik tutumlarında bir değişiklik meydana gelip gelmediğini, ardından varsa bu tutum değişikliğin hangi yönde ve hangi amaçlar doğrultusunda ortaya çıktığını tespit etmek amaçlanmaktadır.

$\mathrm{Bu}$ amaç doğrultusunda ilk olarak ekonomik krizler ve kısaca işletmeler üzerindeki etkilerinden bahsedilmiştir. Ardından muhasebenin kriz yönetimi noktasındaki katkısına değinilmiştir. Son olarak araştırma bölümünde ise, ekonomik kriz dönemlerinde işletmelerin muhasebeye karşı tutamlarındaki değişiklikleri tespit etmek amacıyla muhasebecilerle anket yapılmıştır. Anketin muhasebecilere uygulanmasının nedeni ise, bağımsız çalışan muhasebecilerin aynı anda çok sayıda işletmeye hizmet vermeleri dolayısıyla işletmelerin tutumlarındaki değişiklikleri en iyi gözlemleme imkanına sahip olmalarıdır.

\section{EKONOMIKK KRİLER VE İŞLETMELER ÜZERINNDEKİ ETKİLERİ}

\subsection{Ekonomik Kriz Kavramı}

Kriz kavramı, olağanüstü arzu edilmeyen koşulların oluştuğu ve olağan kabul edilen faaliyetlerin yapılmasını engelleyen hayati bir dönüm noktası olarak ifade edilmektedir (Titiz, 2003:112). Bu anlamda kriz, tüm dünyada olduğu gibi Türkiye'de de özellikle 1980'li yıllardan sonra kendisini daha fazla göstermeye başlamış ve globalleşme ile bu etkileşim daha da hızlanmıştır.

Kriz, "içinden çıkılması zor durum" veya "birdenbire ortaya çıkan kötüye gidiş yönündeki gelişmeler ve tehlikeli an" olarak tanımlanabilmektedir (Akgemci ve Güleş, 2009: 208). Ekonomik Kriz, ekonomide aniden ve beklenmedik şekilde ortaya çıkan olayların makro açıdan ülke ekonomisini, mikro açıdan ise işletmeleri ciddi anlamda sarsacak sonuçlar 
meydana getirmesidir (Kınaytürk, 2006:1). Krizin çıkış1 aniden olmasına rağmen, etkileri uzunca bir süre devam edebilir ve ekonomide her hangi bir dengeyi düzeltirken diğer bir dengeyi bozabilir (Karluk, vd, 1999:2).

Ekonomik kriz bir yandan işletmelerin; girdi, üretim, fiyat, yatırım kararları, istihdam olanakları, kapasite kullanım oranları vb göstergelerde değişiklikler meydana getirir (Daştan, 2009:69) diğer taraftan; ortakların güvenlerinin zedelenmesi, satışlarda düşüşler yaşanması, kârın ve kârlılığın olumsuz etkilenmesi, verimliliğin azalması, prestij kayıplarının olması, dış dünya ile ilişkilerin bozulması (Özdevecioğlu, 2002:94), gibi olumsuzluklara sebep olmaktadır.

\subsection{Ekonomik Krizlerin İşletmeler Üzerindeki Etkileri}

Krizin işletmeler üzerindeki en büyük etkilerinden birisi, kriz döneminde yapılan devalüasyonun neden olduğu öz kaynak kayıplarıdır. Bu kayıp mevcut süreçte kaynak sıkıntısı çeken işletmeleri daha fazla etkilemektedir (TOBB, 2001:6 ; Ekşi, 2007:80).

İşletmeler için yaşanan krizin şekli ve boyutu nasıl olursa olsun mutlaka mali yönüyle işletme üzerinde olumlu veya olumsuz etkisi olmaktadır. Çoğunlukla işletmeler kriz dönemlerinde daha fazla fon kaynaklarına ihtiyaç duyarlar Her dönemde olduğu gibi kriz döneminde de birçok fonlama kaynağı mevcut olabilir. İşletmeye dışarıdan kaynak sağlayanlar, fon şartlarını ağırlaştırdıkları gibi, maliyetleri de artırmaktadırlar. İşletme için zaten kötü giden satışlar, tahsil edilemeyen alacaklar, sürekli değişim gösteren fiyatlar vb. olumsuz etkiler işletmenin kredi bulmasını zorlaştırmaktadır. İşletmeler bu durumda fon ihtiyaçlarını karşılamak için iki alternatif arasında seçim yapma zorunluluğu ile karşı karşıya kalmaktadırlar. Ya işletme içi kaynaklarına başvurarak fon ihtiyacını karşılamaya çalışacak ya da işletme dışı fon sağlayan kurumlara başvuracaktır (Titiz, a.g.m.:117).

Kriz dönemlerinde işletmeleri mali başarısızlığa sürükleyen başlıca sebepler ise aşağıdaki gibi sıralanabilir (Akgüç, 1994:915-916).

- $\quad$ İşletme satışlarının yeterli düzeyde olmaması,

- $\quad$ İşletme giderlerinin, faaliyet hacminin gelişmesinden daha fazla artması,

- İyi bir alacak tahsilat politikasının oluşturulamaması, şüpheli ve batık alacakların sürekli artması,

Borçlanma miktarı ve maliyetinin sürekli artması ya da vadelerinin kısa olması.

Krizin işletmelerin mali tabloları üzerinde de önemli etkileri söz konusudur. Bu etkiler parasal ve parasal olmayan kalemler açısından farklı şekilde olmaktadır (Gücenme, 2002:4851). Enflasyonun etkisi enflasyon hızı, parasal olmayan varlıkların yaşı ve bu varlıkların toplam varlıklara oranının yüksekliği, mali tabloların sunuş dönemlerinin uzunluğuyla doğru orantılı olarak artmaktadır. İzlenen yönetim politikası sonucunda elde yüksek tutarda stok bulundurulması ve stok değerleme yöntemi etkilerin boyutlarını değiştirebilmektedir. Stok devirleri yüksek işletmeler enflasyondan daha az etkilenmektedirler. Ayrıca elde fazla tutarda 
bulundurulan nakdi varlıklar olumsuz etkilere sebep olurken fazla oranda nakdi borç gelir tablosunda olumlu etkiler yaratmaktadır. Aynı şekilde, büyük oranda borçla faaliyetine devam eden bir firma öz kaynakla finanse edilen firmaya göre enflasyondan daha az etkilenmektedir (Çelik, 2003:6).

Genel olarak Ekonomik krizlerin işletmelerin mali tabloları üzerinde meydana getirdiği etkiler ise aşağıdaki gibi oluşmaktadır (Özkan, 2005: 170);

- $\quad$ Kur farklarından büyük zarar veya kar rakamlarının ortaya çıkması,

- $\quad$ Enflasyon dolayısıyla zahiri (fiktif) karların oluşması,

- $\quad$ Sermayenin küçülmesi,

- Stokların artması,

- $\quad$ Tahsilat güçlüklerine bağlı olarak ticari alacakların şüpheli veya değersiz alacak hale dönüşmesi,

- $\quad$ İşçi çıkarılmalarına bağlı olarak ödenen kıdem tazminatlarının artması,

- $\quad$ Ciddi zarar rakamları ile karşı karşıya kalınmasıdır.

\section{MUHASEBENIN KRIZ YÖNETIMINE KATKILARI}

$\mathrm{Bu}$ bölümde muhasebenin kriz yönetimine katkıları; kurumsal yönetim, maliyet yönetimi ve işletme sermayesi yönetimi açısından ele alınacaktır.

\subsection{Kurumsal Yönetim Açısından Katkısı}

Kurumsal yönetim ortaklarca işletme yöneticilerinin kullanımına verilen varlıklar ve değerlerin verimli sonuç verecek biçimde kullanılmasını ve yöneticilerin bu kullanım biçimi ile alınan sonuçlar hakkında ortaklara (ve aslında tüm topluma) hesap verecek durumda bulunmalarını amaçlayan bir sistemler topluluğudur. Bu özelliğiyle kurumsal yönetim, dar anlamda bir işletmenin, ortaklarıyla ilişkilerini düzenleyen sistemler topluğu, geniş anlamda da işletme ile toplumun ilişkilerini düzenleyen sistemler topluluğu biçiminde tanımlanabilir. Öte taraftan muhasebe organizasyonun planlamasına, gelişimine ve operasyonel ve finansal durumun iyileştirilmesine yönelik bilgi üretimini sağlamaktadır. Ayrıca muhasebe bilgi sistemi, organizasyon yöneticilerine yönelik olarak direkt bilgi sunumunda bulunmaktadır (Bushman ve Smith, 2001). Özellikle şeffaf, hesap verebilir ve sorumluluk anlayışına dayalı finansal bilgi raporlarının düzenlenmesinde muhasebe bilgi sistemine önemli sorumluluklar düşmektedir. $\mathrm{Bu}$ kapsamda işletmenin muhasebe bilgi sisteminden beklentileri ancak işletmede geçerli kurumsal yönetim anlayışı ile sağlanabilecektir (Özkol vd.,2005:135). İşletmelerin sürekliliğini sağlayacak ve uzun süreli karlı, sağlıklı büyümelerini güven altına alacak kurumsal yönetim uygulamalarının kurumsal yönetim mekanizmalarınca oluşturulması ve devamlılığının sağlanması büyük ölçüde muhasebeden sağlanan bilgiler ile mümkün olabilecektir (Aysan, 2007:19). 
$\mathrm{Bu}$ noktada muhasebe sistemi, kurumsal yönetim mekanizmalarına işletmenin amaçlarına ulaşmasında sağlıklı kararlar alınabilmesi için gerekli bilgilerin en doğru ve hızlı bir şekilde iletiminin sağlandığı bir araç olması yanında uygulamaların performans sonuçlarının değerlendirmesinde de temel veri kaynağını oluşturmaktadır. Ayrıca bilgiyi zamanında ve gerekli yerlere ulaştıran muhasebe bilgi sistemi, kurumsal yönetim uygulamalarının, işletme içerisinde gelişmesi ve yaygınlaşması açısından son derece önemli bir araçtır. Görüldüğü üzere kurumsal yönetim anlayışı ile muhasebe sisteminin etkileşimi karşılıklı ve olumlu yönde olup her ikisinin birbirine olan katkısı ve uygulamalardaki etkinliği, işletme verimliliğini, karlılığını ve değerini olumlu yönde etkilemektedir. Dünya üzerindeki gelişmeler dikkatlice izlendiğinde, kurumsal yönetimin muhasebe olgusu ile iç içe olduğu, dolayısıyla kurumsal yönetimdeki başarının muhasebe uygulamasındaki şeffaflık, adillik, hesap verilebilirlik ve sorumluluk ilkeleri ile bütünleştiği anlaşılmaktadır (Seviğg,2005).

Günümüzde işletme yönetiminin temel görevi küreselleşen dünyada meydana gelen hızlı değişimi sürekli izlemek, özellikle kriz dönemlerinde gerekli önlemleri alarak işletme sürekliliğini ve varlıklarının korunmasını sağlamaktır. İşletme yönetimi söz konusu görevi etkin bir kriz yönetimi ile gerçekleştirebilir. Kriz yönetiminin planlama, yönetme ve kontrol gibi faaliyetlerdeki etkinliği ise muhasebe bilgi sistemi tarafından sağlanan doğru, tarafsız ve güvenilir bilgilerle sağlanabilir.

Muhasebenin kriz dönemlerinde işletme yönetimine katkısı aşağıdaki başlıklar altında değerlendirilebilir (Daştan, a.g.m., 65);

- Erken uyarı sistemleri kurma ve karar süreçlerinde çabukluk açısından yönetime katkı sağlama,

- Kurumsal yönetim konusunda yönetime katkı sağlama,

- $\quad$ Sürekli maliyet düşürme ve tasarruf stratejileri oluşturmada yönetime katkı sağlama,

- $\quad$ Etkin muhasebe iletişimi ile yönetime katkı sağlama,

- $\quad$ Nakit ve çalışma sermayesi yönetimi konusunda yönetime katkı sağlamadır.

Kurumsal yönetim, çıkar gruplarının haklarını korumayı ve işletme yönetimin sorumluluk ve yükümlülüklerini ortaya koymayı amaçlayan bir yönetim felsefesi (Aktan, 2009: 2), olmasının yanı sıra işletmelerin sağlam bir kurumsal yapıya kavuşması ve böylece krizlere karşı daha güçlü olmasına da katkı sağlamaktadır.

\subsection{Maliyet Yönetimi Açısından Katkısı}

Muhasebe maliyet unsurları ile ilgili ayrı ayrı ya da toplu olarak hızlı analiz yaparak doğru ve güvenilir maliyet bilgileri üretmektedir. Üretilen bilgiler, maliyetler açısından olumsuzlukların yaşandığı faaliyet alanları ile ilgili olarak yönetimin gerekli tedbirleri zamanında alabilmesi bakımından yönetime önemli katkı sağlamaktadır. Unutulmamalıdır ki 
sürekli maliyet iyileştirme anlayışı ve maliyet yönetimindeki başarı ekonomik kriz dönemlerinde işletmelerin krize kısa sürede uyum sağlamasını ve en az tahribatla krizden kurtulmasını sağlayabilecektir (Şakrak, 1999: 54).

Ekonomik kriz dönemlerinde tasarruf stratejileri bir diğer önlem tedbiri olarak ele alınıp uygulanabilir. Tasarruf stratejileri arasında; idari işlemlerde harcamaların azaltılması, borçlanmadan ziyade öz sermaye ile çalışmaya ağırlık verilmesi, alacaklarda tahsilatın artırılması ve hızlandırılması, iç ve dış pazarlarda satış ve pazarlamaya ağırlık verilmesi, vadeli satışlardan kaçınılması ve satışların nakit olarak gerçekleştirilmesine önem verilmesi sayılabilir. Söz konusu tüm tasarruf stratejilerinin uygulanmasında doğru adımların atılabilmesi ve başarıya ulaşılabilmesi için muhasebenin ürettiği güvenilir verilere ihtiyaç bulunmaktadir.

\section{3. İşletme Sermayesi Yönetimi Açısından Katkısı}

Ekonomik krizlerin yaşandığı bir dönem de doğal olarak işletmeler gerek sistematik gerekse sistematik olmayan risklerle karşı karşıya kalabilmektedir. Bu risklerin olumsuz sonuçları daha çok yabancı piyasalarda faaliyet gösteremeyen yeni pazar olanakları kısıtlı olan ve ticari faaliyetlerini sorunsuz yerine getirecek likidite düzeyi zayıf olan işletmeleri daha çok etkilemektedir.

Ekonomik kriz işletme satışlarının azalmasına ve buna bağlı olarak da nakit girişlerinin azalmasına neden olmaktadır. Diğer taraftan tahsilat gecikmesine bağlı olarak, nakit çıkısı, nakit girişinden fazla olabilmektedir. $\mathrm{Bu}$ nedenle kriz dönemlerinde nakit yönetiminin önemi daha da artmaktadır (Sarıkamış, 2000: 51). Kriz dönemlerinde stokların artması ve alacak tahsilâtının yavaşlaması nakit dönüşüm süresinin uzamasına neden olmakta, bu da finansman ihtiyacını artırmaktadır (Birgili ve Tunahan, 2002:14).

İşletme sermayesi yönetimi bilançodaki dönen varlıkları konu edinir ve işletme faaliyetlerinin kesintiler olmadan sürdürülebilmesi, vadesi gelen borçların zamanında ödenebilmesi, borçlanma olanaklarının arttırılması ve işletmenin kârlılık ve büyüme hedeflerine başarıyla ulaşabilmesi yönlerinden önem taşımaktadır. İşletme sermayesi yönetimi, risk ve kârlılık arasında uygun bir dengenin kurulmasını gerektirir. Çünkü işletme sermayesinin atıl kalması kârlılığın azalmasına yol açarken, işletme sermayesi açığı da işletmenin ödeyememe riskini artırır. (Şakrak, a.g.m., 56). Kriz dönemlerinde işletme sermayesi unsurlarının yönetimi daha da zorlaşmakla birlikte, risk ile karlılık arasındaki dengeyi kurmak da her zamankinden daha zor hale gelmektedir.

Özetle özellikle kriz dönemlerinde işletmelerin işletme sermayesi unsurlarını başarılı bir şekilde yönetebilmeleri noktasında doğru karar verebilmeleri için yeterince hızlı, esnek ve doğru hareket kabiliyeti sağlayabilecek bilgi ve belgeler muhasebe bilgi sistemince sağlanmalıdır (Daştan, a.g.m., 69) 


\section{LITERATÜR ARAŞTIRMASI}

Literatürde ekonomik krizler ile muhasebe disiplinin ilişkisini doğrudan veya dolaylı olarak konu edinen, farklı farklı yaklaşımlarla konuyu elan alan bir takım çalışmalara rastlanmaktadır. Bu çalışmalar ve elde edilen sonuçlar özetle şu şekildedir.

Daştan (2009) tarafından yapılan çalışmada muhasebe bilgi sistemi tarafından üretilen ve isletme yönetimine sunulan finansal bilgiler kriz dönemlerinde daha önemli hale geldiği ifade edilmektedir. Çünkü kriz dönemlerinde işletme yönetiminin hızlı ve etkin karar vermesini sağlayabilecek tam, güvenilir, tarafsız, açık ve anlaşılabilir bilgi gereksinimi iyice artmaktadır. Gereksinimlerin karşılanması bağlamında muhasebe bilgi sistemi kriz dönemlerinde işletme yönetimine; erken uyarı sistemleri kurma ve karar süreçlerinde çabukluk, kurumsal yönetim, sürekli maliyet düşürme ve tasarruf stratejileri oluşturma, etkin iletişim ile nakit ve çalışma sermayesi yönetimi konularında katkı sağlayabilir. (Daştan, a.g.m.,70).

Can (2010) yaptığı çalışmada, krizin mevcut muhasebe ve denetim sistemi ve uygulamalarından kaynaklanan bir bir kriz olması durumunda çözümün de muhasebe ve denetim içerisinde aranması gerektiği, bu nedenle muhasebe ve denetimin de krizden sorumlu tutulması gerektiği belirtilmiştir. Dolayısıyla muhasebe ve denetimin esas kimliğine bürünerek krizi tersine çevirecek girişimlere katkıda bulunmak ve tüm toplumun çıkarlarını koruma görevinin büyük parçası olmak zorunda olduğu, ideal olanın muhasebe ve denetim sistemlerinin krizlerin ortaya çıkmasını önleyebilecek yapıda yeniden tasarlanmalarını sağlamak gerektiği sonucuna ulaşılmıştır.

Karacan ve Savcı (2011) yaptıkları çalışmada, bir işletmede kriz dönemlerinde, yönetimin yeterliliği, kaynak sağlanması ve kaynağın kullanılmasındaki etkinlik ve kaliteden ödün vermeden maliyetleri asgarileştirmenin önem taşımakta olduğu belirtilmiştir. İşletmelerin bu dönemlerde, mali başarısızlığa uğramadan kârlılık ve yaşamlarını sürekli kılmaları; örgüt geliştirmeye, etkin bir muhasebe sistemine, sağlam kaynak yapısına, değişime ve yeniliklere açık olup, geleceğin öngörülebilmesine, tüketicilerin isteklerini kaliteden ödün vermeden istenilen maliyet, zaman, miktar ve yerde üretmesine, mal veya hizmete değer katmayan tüm faaliyetlerin elenmesine, riskleri yönetme becerisine ve kriz dönemlerinde oluşabilecek tehditleri fırsatlara dönüştürebilmesine bağlı olduğu sonucuna ulaşmışlardır.

Metal sanayinde faaliyette bulunan büyük bir şirkette görev yapan üst ve orta düzey yöneticiler üzerinde 2002 yılında gerçekleştirilen bir araştırmada, kriz yönetimi sürecinin aşamaları açısından bir irdeleme yapıldığında, stratejik yönetim sisteminin; krizden kaçınma, krizi çözme ve krizden yarar sağlamada yöneticilere kısmen destek sağladığı sonucuna ulaşılmıştır (Karakaya, 2004: 231).

2010 y1lında Eskişehir, İstanbul, Kütahya, Adana, Çorum, Düzce ve Kahramanmaraş illerinde faaliyet gösteren küçük ve orta ölçekli isletmeler üzerine yapılan "kriz ortamında işletme yöneticilerinin tutumları ve muhasebe meslek mensuplarından beklentileri" başlıklı 
araştırmada KOBİ'lerin krizin etkilerini hissederek değişen dış çevre şartlarına uyum sağlamaya çalıştıkları sonucuna ulaşılmıştır. Ayrıca temel muhasebe hizmetleri ve maliyet ve verimlilik çalışmalarında yardım konusunda muhasebe meslek mensuplarından yüksek düzeyde, yatırım kararlarında yardım konusunda nispeten yüksek düzeyde beklentilere sahip oldukları, diğer taraftan krizin fırsat olarak görülmediği, çözüm konusunda muhasebeden elde edilecek bilgilerin çok fazla önemsenmediği, muhasebe süreçlerine yeteri kadar önem verilmediği ve isletmenin stratejik kararlarında muhasebe meslek mensuplarından orta seviyede beklentilere sahip olduklarının söylenebileceği sonucuna ulaşılmıştır (Yalçın, 2010:112).

\section{ARAȘTIRMANIN METODOLOJISİ}

\subsection{Amaç}

Ekonomik krizlerin yaşandığı dönemlerde işletme sahip ve yöneticileri işletmelerinin krizden en az etkilenmesi için her zamankinden daha fazla dikkat ve özen göstermek zorundadırlar. Bu dönemlerde özellikle işletmenin finansal verilerinin daha dikkatli izlenmesi ve olası risklere karşı gerekli önleyici adımların atılması gerekir. Dolayısıyla kriz dönemlerinde işletme yöneticilerinin muhasebeye ve muhasebe verilerine daha fazla önem vermeleri ve ilgi göstermeleri beklenir. Bu bağlamda çalışmada, ekonomik kriz dönemlerinde işletmelerin muhasebeye karşı tutumlanındaki değişiklikleri ve bu değişikliklerin ne yönde ortaya çıktığını tespit etmek amaçlanmaktadır.

\subsection{Anket ve Örneklem}

Kriz dönemlerinde işletmelerin muhasebeye karşı tutumlarındaki değişiklikleri tespit etmeyi amaçlayan çalışmaya veri toplamak için muhasebe meslek mensuplarına 12 ifadeden oluşan bir anket uygulanmıştır. Muhasebecilere ankette yöneltilen ifadelere 1=Kesinlikle Katılmiyorum, 2=Katılmiyorum, 3=Kararsızım, 4= Katılıyorum ve 5= Kesinlikle Katıliyorum şeklinde cevap vermeleri istenmiştir. Anketin muhasebe meslek mensuplarına yönelik olarak yapılmasının sebebi ise; çok sayıda işletme ile sürekli iletişim içerisinde olmalarından dolayı işletmelerin muhasebeye karşı tutumlarını en iyi gözlemleyebilen kişiler olmalarıdır.

Araştırmanın evrenini bağımsız çalışan muhasebeciler oluşturmaktadır. Türkiye'de toplam 49.704 bağımsız muhasebe meslek mensubu bulunmaktadır (TURMOB). \%95 anlamlılık düzeyinde 49.704 kişilik ana kütle için $\pm 0,05$ örneklem hatası ( $p=0,5 ; q=0,5)$ ile minimum düzeyde örneklem sayısı 382 olarak hesaplanmaktadır. (Yazıcığlu ve Erdoğan, 2004:50). Bu kapsamda tesadüfi olarak seçilen illerde faaliyet gösteren 400 muhasebe meslek mensubu ile anket gerçekleştirilmiştir. Elde edilen anket formlarından 39'u analize elverişli olmadığı için kapsam dışında bırakılmış ve toplamda 361 anket formu analize dahil edilmiştir. 


\subsection{Yöntem}

Anketler ulaşılabilme olanakları göz önünde bulundurularak tesadüfi olarak seçilen illerdeki yine tesadüfi olarak seçilen muhasebeciler tarafından doldurulmuştur. Anketlerin çok büyük bir bölümü yüz yüze görüşme yoluyla uygulanmıştır. Anketlerden elde edilen veriler SPSS 17.0 programı yardımıyla analiz edilmiştir. Bu kapsamda sırasıyla güvenilirlik analizi, $\mathrm{T}$ testi ve korelasyon analizleri yapılmıştır.

\subsection{Analiz ve Bulgular}

\subsubsection{Demografik Verilerin Analizi}

Araştırma kapsamında anket uygulanan muhasebecilerin demografik özelliklerine ilişkin frekans ve yüzde dağılımları Tablo 1'de verilmektedir.

Tablo 1: Muhasebecilerin Demografik Özellikler (n:361)

\begin{tabular}{|l|l|l|l|}
\hline \multirow{4}{*}{ Mesleki Unvan } & & Frekans & \% \\
\hline \multirow{4}{*}{ Cinsiyet } & SM & 44 & 12,2 \\
\cline { 2 - 4 } & SMM & 317 & 87,8 \\
\hline \multirow{5}{*}{ Yaş } & Erkek & 284 & 78,7 \\
\cline { 2 - 4 } & Bayan & 77 & 21,3 \\
\hline \multirow{5}{*}{ Eedeni Durum } & $18-24$ aras1 & 10 & 2,8 \\
\cline { 2 - 4 } & $25-30$ aras1 & 36 & 10 \\
\cline { 2 - 4 } & $31-40$ & 142 & 39,3 \\
\cline { 2 - 4 } & $41-50$ aras1 & 111 & 30,7 \\
\cline { 2 - 4 } & $51-60$ aras1 & 62 & 17,2 \\
\hline \multirow{5}{*}{ Mesleki Deneyim Süresi } & Evli & 304 & 84,2 \\
\cline { 2 - 4 } & Bekar & 57 & 15,8 \\
\hline & Lise & 55 & 15,2 \\
\cline { 2 - 4 } & Ön Lisans & 27 & 7,5 \\
\cline { 2 - 4 } & Lisans & 263 & 72,9 \\
\cline { 2 - 4 } & Lisans Üstü & 16 & 4,4 \\
\hline & $1-5$ y1l aras1 & 54 & 15 \\
\cline { 2 - 4 } & 6-10 y1l aras1 & 50 & 13,9 \\
\cline { 2 - 4 } & $11-15$ y1l aras1 & 111 & 30,7 \\
\cline { 2 - 4 } & $16-20$ y1l aras1 & 32 & 8,9 \\
\cline { 2 - 4 } & 20 y1l ve üzeri & 114 & 31,6 \\
\hline
\end{tabular}

Araştırmaya katılan muhasebecilerin demografik özelliklerinden öne çıkan bazı hususlar şu şekildedir. Araştırmaya katılanların \%86,7'si SMM, \%78,7'si erkek ve \%84,2'si ise evlidir. Yaş dağılımında ise en büyük oranı \%39,3 ile 31-40 yaş aralığındaki muhasebeciler oluşturmaktadır. Diğer taraftan araştırmaya katılan muhasebecilerin \% 72,9'unu 
lisans mezunları ve $\% 31,6$ 'sı ise 20 yıl ve üzeri mesleki tecrübeye sahip olanlar oluşturmaktadır.

\subsubsection{Güvenilirlik Analizi}

Araştırma kapsamında uygulanan anketin güvenirlik analizleri sonucunda Cronbach Alfa katsayısı 0,888 olarak hesaplanmıştır. Elde edilen bu alfa katsayısına göre yapılan anketin yüksek derecede güvenilirliğe ve iç tutarlılığa sahip olduğu tespit edilmiştir. (Kalaycı, 2006: 405).

\subsubsection{Tanımlayıcı İstatistikler ve $T$ testi}

Anket formunda muhasebecilere yöneltilen ifadelere 1=Kesinlikle Katılmıyorum, 2=Katılmıyorum, 3=Kararsızım, 4= Katılıyorum ve 5= Kesinlikle Katılıyorum şeklinde verilen cevaplara ilişkin tanımlayıcı istatistikler ile t testi sonuçları Tablo 2'de verilmektedir.

Tablo 2: Anket Sorularına Verilen Cevapların İstatistiksel Sonuçları (n=361)

\begin{tabular}{|l|c|c|c|c|}
\hline \multicolumn{1}{|c|}{ İfadeler } & Mean & $\begin{array}{c}\text { Std. } \\
\text { Deviation }\end{array}$ & t & Sig. \\
\hline $\begin{array}{l}\text { Devlete karşı olan sorumluluklarını zamanında yerine getirmek ve } \\
\text { cezaya maruz kalmamak için muhasebeye daha fazla önem verirler }\end{array}$ & 3,79 & 1,148 & 13,081 &, 000 \\
\hline Daha az vergi ödemek için muhasebeye daha fazla önem verirler & 3,76 & 1,232 & 11,764 &, 000 \\
\hline $\begin{array}{l}\text { Maliyetleri hesaplama ve azaltmaya yönelik çalışmalara daha fazla } \\
\text { önem verirler }\end{array}$ & 3,67 & 1,101 & 11,635 &, 000 \\
\hline $\begin{array}{l}\text { Muhasebecilerinden mali konularda daha fazla } \\
\text { bilgilendirme/danışmanlık yapmalarını isterler }\end{array}$ & 3,63 & 1,237 & 9,619 &, 000 \\
\hline $\begin{array}{l}\text { Muhasebecileriyle daha sık görüşürler } \\
\text { Nakit, alacak ve stok yönetimi gibi işletme sermayesi yönetimi } \\
\text { çalışmalarına daha fazla önem verirler }\end{array}$ & 3,43 & 1,319 & 6,145 &, 000 \\
\hline $\begin{array}{l}\text { Yatırım, borçlanma vb. kararlarında muhasebe verilerinden daha } \\
\text { fazla yararlanırlar }\end{array}$ & 3,27 & 1,159 & 6,591 &, 000 \\
\hline $\begin{array}{l}\text { Krizden en az zararla çıkabilmek için muhasebenin desteğinin } \\
\text { önemli olduğunu düşünürler }\end{array}$ & 3,26 & 1,213 & 4,079 &, 000 \\
\hline $\begin{array}{l}\text { Yönetim kararlarına destek sağlamak ve daha başarılı bir yönetim } \\
\text { ortaya koymak açısından muhasebeye daha fazla önem verirler }\end{array}$ & 3,20 & 1,200 & 2,867 &, 002 \\
\hline $\begin{array}{l}\text { Kriz yönetim stratejilerini belirlemek açısından muhasebeye daha } \\
\text { fazla önem verirler }\end{array}$ & 3,19 & 1,250 & 2,867 &, 004 \\
\hline Finansal tablolara daha fazla ilgi gösterirler & 3,06 & 1,275 &, 826 &, 409 \\
\hline $\begin{array}{l}\text { "Vergi İçin Muhasebe” anlayışından çok "Bilgi İçin Muhasebe” } \\
\text { anlayışını öne çıkarırlar }\end{array}$ & 2,89 & 1,369 & $-1,499$ &, 135 \\
\hline
\end{tabular}

Araştırmaya katılan muhasebecilerin kendilerine yöneltilen 12 ifadeye vermiş oldukları cevaplara \%95 güven düzeyinde $\mathrm{t}$ testi uygulanmıştır. Yapılan $\mathrm{t}$ testi ankete katılanların vermiş oldukları cevapların 3=Kararsızım düzeyinden anlamlı bir şekilde farklılaşıp farklılaşmadığını tespit etmeyi amaçlamaktadır. Ayrıca her bir ifadeye verilen cevapların ortalamaları alınmak suretiyle en yüksek katılma düzeyinden en düşük olana doğru sıralanmıştır. Verilen cevaplar 3'ün üzerine çıktıkça muhasebecilerin o ifadeye olumlu yönde, 3’ün altına indikçe de olumsuz yönde katıldıkları anlaşılmaktadır. 
Bu bağlamda tablo 2'de yer alan sonuçlara bakıldığında ankette yer alan 12 ifadeden 11 'ine katılma düzeylerinin 3'ten daha yüksek düzeyde olduğu görülmektedir. Ayrıca 10 ifadeye verilen cevaplar kararsızlık düzeyinden istatistiksel olarak anlamı bir şekilde farklılaşmaktadır. Bu sonuç özetle; işletmelerin genel olarak kriz dönemlerinde muhasebeye karşı tutamlarında istatistiksel olarak anlamlı düzeyde bir değişiklik meydana geldiği şeklinde değerlendirilebilir.

Diğer taraftan muhasebecilerin katılma yönünde en yüksek puan verdikleri ifade "Devlete karşı olan sorumluluklarını zamanında yerine getirmek ve cezaya maruz kalmamak için muhasebeye daha fazla önem verirler" olmuştur. Elde edilen bu sonucun aynı zamanda istatistiksel olarak da anlamlı olduğu görülmektedir. Benzer şekilde yine ifadeler arasından katılma yönünde ikinci en yüksek puana sahip ifade de "Daha az vergi ödemek için muhasebeye daha fazla önem verirler" şeklinde olmuştur. Bu sonuçlara bakıldığında ekonomik kriz dönemlerinde işletmelerin muhasebeye karşı tutamlarında meydana gelen değişikliğin öncelikle devlete karşı olan sorumluluklarını zamanında yerine getirme ve daha az vergi ödeme gayesine dayandığı tespit edilmektedir. Bununla birlikte, işletmelerin tutumlarında "Maliyetleri hesaplama ve azaltmaya yönelik çalışmalara daha fazla önem verme" ve "muhasebecilerinden daha fazla danışmanlık desteği isteme" yönünde de bir değişiklik meydana gelmektedir.

Aşağıdaki ifadelerden ikisi ise muhasebeciler tarafından düşük puanlanmış ve istatistiksel olarak da anlamsız olduğu sonucuna ulaşılmıştır. Ankette yer alan "finansal tablolara daha fazla ilgi gösterirler" ve "vergi için muhasebe anlayışından çok bilgi için muhasebe anlayışını öne çıkarırlar" ifadeleri kararsızlık seviyesine çok yakın veya altında puanlanmış olup aynı zamanda istatistiksel olarak da anlamsızdır.

Özetle ankete katılan muhasebecilerin ekonomik kriz dönemlerinde işletmelerin muhasebeye karşı tutamlarındaki değişikliklere ilişkin düşünceleri şöyledir. İşletmeler kriz dönemlerinde öncelikle devlete karşı yasal sorumluluklarını yerine getirme ve herhangi bir cezaya maruz kalmamak açısından muhasebeye daha fazla ilgi göstermektedirler. Onun ardından daha az vergi ödemek için muhasebeye daha fazla önem vermektedirler ifadesi gelmektedir. $\mathrm{Bu}$ sonuçlara göre işletmelerin açıkça kriz dönemlerinde muhasebeye karşı tutumlarında bir değişikliğin meydana geldiği, ancak bu değişikliğin krizi daha iyi yönetmek veya krize karşı önlemler almaktan çok, devletle herhangi bir sorun yaşamamak ve daha az vergi ödemek yönünde ortaya çıktığı tespit edilmiştir.

\subsubsection{Korelasyon Analizi}

Araştırma kapsamında uygulanan anketlerde yer alan ifadeler arasında istatistiksel olarak anlamlı bir ilişki olup olmadığını tespit edebilmek amacıyla 12 ifadeden oluşan anketler korelasyon analizine tabi tutulmuştur. \%99 güven düzeyinde yapılan analiz sonucunda aralarında en güçlü korelasyonun bulunan ifadeler Tablo 3'de verilmiştir. 
Tablo 3: Ankette Yer Alan İfadeler Arasındaki Korelasyonlar

\begin{tabular}{|c|c|c|}
\hline \multirow{3}{*}{$\begin{array}{l}\text { Devlete karşı olan sorumluluklarını zamanında } \\
\text { yerine getirmek ve cezaya maruz kalmamak için } \\
\text { muhasebeye daha fazla önem verirler }\end{array}$} & \multicolumn{2}{|c|}{$\begin{array}{l}\text { Daha az vergi ödemek için muhasebeye daha fazla } \\
\text { önem verirler }\end{array}$} \\
\hline & Pearson Corelation &, $0396 * *$ \\
\hline & Sig. (2-tailed) &, 000 \\
\hline \multirow[t]{3}{*}{$\begin{array}{l}\text { Maliyetleri hesaplama ve azaltmaya yönelik } \\
\text { çalışmalara daha fazla önem verirler }\end{array}$} & \multicolumn{2}{|c|}{$\begin{array}{l}\text { Nakit, alacak ve stok yönetimi gibi işletme sermayesi } \\
\text { yönetimi çalışmalarına daha fazla önem verirler }\end{array}$} \\
\hline & Pearson Corelation &, $528 * *$ \\
\hline & Sig. (2-tailed) &, 000 \\
\hline \multirow{3}{*}{$\begin{array}{l}\text { Muhasebecilerinden mali konularda daha fazla } \\
\text { bilgilendirme/danışmanlık yapmalarını isterler }\end{array}$} & \multicolumn{2}{|c|}{ Muhasebecileriyle daha sık görüşürler } \\
\hline & Pearson Corelation & ,684** \\
\hline & Sig. (2-tailed) & ,000 \\
\hline \multirow[t]{3}{*}{$\begin{array}{l}\text { Yatırım, borçlanma vb. kararlarında muhasebe } \\
\text { verilerinden daha fazla yararlanırlar }\end{array}$} & \multicolumn{2}{|c|}{$\begin{array}{l}\text { Yönetim kararlarına destek sağlamak ve daha başarılı } \\
\text { bir yönetim ortaya koymak açısından muhasebeye daha } \\
\text { fazla önem verirler }\end{array}$} \\
\hline & Pearson Corelation &, $506 * *$ \\
\hline & Sig. (2-tailed) & ,000 \\
\hline \multirow[t]{3}{*}{$\begin{array}{l}\text { Krizden en az zararla çıkabilmek için muhasebenin } \\
\text { desteğinin önemli olduğunu düşünürler }\end{array}$} & \multicolumn{2}{|c|}{$\begin{array}{l}\text { Kriz yönetim stratejilerini belirlemek açısından } \\
\text { muhasebeye daha fazla önem verirler }\end{array}$} \\
\hline & Pearson Corelation &, $606 * *$ \\
\hline & Sig. (2-tailed) & ,000 \\
\hline \multirow{3}{*}{$\begin{array}{l}\text { "Vergi İçin Muhasebe" anlayışından çok "Bilgi İçin } \\
\text { Muhasebe" anlayışını öne çıkarırlar }\end{array}$} & \multicolumn{2}{|c|}{ Finansal tablolara daha fazla ilgi gösterirler } \\
\hline & Pearson Corelation & ,435** \\
\hline & Sig. (2-tailed) & ,000 \\
\hline
\end{tabular}

Yapılan korelasyon analizi sonucunda ankette yer alan her ifadenin diğer ifadelerle arasında istatistiksel olarak anlamlı korelasyonlar tespit edilmiştir. Bu ifadelerden sadece en güçlü korelasyon içerisinde bulunduğu tespit edilen ifadeler tablo 3'de yan yana verilmiştir. Örneğin "Devlete karşı olan sorumluluklarını zamanında yerine getirmek ve cezaya maruz kalmamak için muhasebeye daha fazla önem verirler" ifadesinin en güçlü korelasyon içerisinde bulunduğu ifadenin "daha az vergi ödemek için muhasebeye daha fazla önem verirler" olduğu tespit edilmiştir. Bu iki ifadenin verilen cevapların ortalama değerleri açısından da en yüksek katılma düzeyine sahip ilk iki ifade olduğunu hatırlamakta yarar vardır. Bu iki ifade arasında \%99 güven seviyesinde 0,396 düzeyinde aynı yönlü istatistiksel olarak anlamlı bir ilişki bulunmaktadır. Başka bir ifadeyle "devlete karşı sorumluluklarını zamanında yerine getirmek ve cezaya maruz kalmamak için muhasebeye daha fazla önem verirler" ifadesine katılanların aynı zamanda "daha az vergi ödemek için muhasebeye daha fazla önem verirler" ifadesine de katılım gösterdikleri görülmektedir. Mantıksal olarak bu iki ifadenin pozitif yönde bir korelasyon içerisinde bulunması beklenen bir durumdur. Çünkü kriz dönemlerinde devlete karşı sorumluluklarını aksatmadan yerine getirmeyi öncelikli olarak değerlendiren bir işletmenin daha az vergi ödemek gayesi öncelemesi da son derece normal olarak kabul edilebilir. 
Benzer şekilde "maliyetleri hesaplama ve azaltmaya yönelik çalışmalara daha fazla önem verirler" ifadesi ile "nakit, alacak ve stok yönetimi gibi işletme sermayesi yönetimi çalışmalarına daha fazla önem verirler" ifadesi arasında da yine istatistiksel olarak anlamlı ve aynı yönlü güçlü bir korelasyon $(0,528)$ bulunmaktadır. Diğer bir değişle, maliyetlerini azaltmaya yönelik çalışmaları nedeniyle muhasebeye daha fazla önem verenlerin, aynı zamanda işletme sermayesi unsurlarını daha iyi yönetebilme gayesini güttükleri görülmektedir. Bu iki ifade arasındaki korelasyon da yine yukarıdaki ifadelerde olduğu gibi mantıksal olarak anlamlı ve beklenen bir durum olarak değerlendirilebilir. Çünkü aralarında pozitif yönlü güçlü bir korelasyon bulunan bu iki ifade, muhasebeden daha çok karar desteği sağlamaya yönelik yararlanmak isteyen işletmelerin bakış açısını temsil etmektedir.

Ardından "muhasebecilerinden mali konularda daha fazla bilgilendirme veya danışmanlık yapmalarını isterler" ifadesi ile "muhasebecileri ile daha sık görüşürler" ifadeleri arasında da güçlü bir korelasyon $(0,684)$ söz konusudur. Muhasebecisinden danışmanlık desteği anlamında daha fazla yararlanmak isteyen bir işletmenin muhasebecisi ile daha sik görüşme tutumu göstermesi oldukça anlamlı ve beklenen bir durumdur.

Son olarak korelasyon analizi sonuçlarında dikkat çeken bir başka sonuç ise; "krizden en az zararla çıkabilmek için muhasebenin desteğinin önemli olduğunu düşünürler” ifadesi ile "kriz yönetim stratejilerini belirlemek açısından muhasebeye daha fazla önem verirler" ifadesi arısındaki pozitif yönlü ve güçlü korelasyondur $(0,606)$. Bu sonuç ta; krizden en az zararla çıkabilmek için muhasebenin önemine inanan işletmelerin, kriz yönetim stratejilerini belirleme noktasında da muhasebeye verdikleri önemin arttığını ifade etmektedir. Yine krizden en az zararla çıkabilme düşüncesiyle kriz yönetim stratejilerini belirleme arasındaki bu ilişki de oldukça anlamlı ve beklenen bir durum olarak değerlendirilebilir.

\section{SONUÇ}

Meydana gelen ekonomik krizler şüphesiz işletmeleri çeşitli açılardan etkilemektedir. Krizin oluştuğu sektör ve bölgeye göre etkilenme düzeyinde farklılıklar olmakta birlikte, işletmelerin; talep düşmesi nedeniyle satışlarda azalma, stoklarda artma, alacak tahsilinde sorunlarla karşılaşma, borçlanma olanaklarında daralma gibi problemlerle karşılaşmaları muhtemel gözükmektedir. Söz konusu problemlerle ekonomik kriz, işletmelerin girdi, üretim, fiyat, yatırım kararları, istihdam imkanları, kar marjları, kalite düzeyleri, kapasite kullanım oranları gibi göstergelerde değişiklikler meydana getirir. Bu değişiklikler doğal olarak muhasebe bilgi sistemi aracılığıyla işletmelerin mali tablolarına yansır. Ekonomik krizlerin mali tablolar üzerinde meydana getirdiği etkiler, kur farklarına dayalı kar veya zarar rakamları, enflasyon dolayısıyla oluşan fiktif karlar, sermayenin değerinde düşüş, stok miktarlarında artış, tahsilat güçlüklerine bağlı olarak ticari alacakların şüpheli alacak haline dönüşmesi seklinde sıralanabilir.

İşletmelerde mali tabloları düzenlemekle dolayısıyla, finansal bilgi üretimini sağlamakla görevli muhasebe bilgi sistemi, yönetimin varlıklar üzerindeki yönetim 
sorumluluğunu yerine getirmesi, işletme faaliyetlerinin kontrolünü sağlaması ve geleceğe ilişkin işletme faaliyetlerinin planlaması için gerekli bilgileri sağlamayı amaçlamaktadır. Muhasebe bilgi sistemi aracılığıla sunulan muhasebe bilgileri yöneticilere hedef belirleme, değişik karar seçeneklerini tanımlama, değerleme, bunlar arasında tercih yapma gibi katkılar sağlamaktadır.

Muhasebe bilgi sistemi tarafından üretilen ve işletme yönetimine sunulan finansal bilgiler kriz dönemlerinde daha önemli hale gelmektedir. Çünkü kriz dönemlerinde işletme yönetiminin hızlı ve etkin karar vermesini sağlayabilecek tam, güvenilir, tarafsız, açık ve anlaşılabilir bilgi gereksinimi iyice artmaktadır. Gereksinimlerin karşılanması bağlamında muhasebe bilgi sistemi kriz dönemlerinde işletme yönetimine; erken uyarı sistemleri kurma ve karar süreçlerinde çabukluk, kurumsal yönetim, sürekli maliyet düşürme ve tasarruf stratejileri oluşturma, etkin iletişim ile nakit ve çalışma sermayesi yönetimi konularında katkı sağlayabilir.

Muhasebe uygulamalarının, beklenilen kalitede oluşması için; öncelikle meslek mensuplarının mesleğe gereken önemi vermeleri, uygulamalarını etik kuralları ihlal etmeden gerçekleştirmeleri, muhasebe uygulamalarının küresel gelişmelere uyumlu olarak geliştirilmesi için meslek örgütlerinin, devletin, müşterilerin, akademik çevrelerin etkileşimine olanak sağlayacak platformların oluşturulması gerekmektedir.

Bilindiği üzere ülkemizde bağımsız muhasebe meslek mensupları, çok çeşitli faaliyet kollarında ve farklı büyüklüklerdeki işletmelerin muhasebe işlemlerini bir arada gerçekleştirmektedirler. Başka bir değişle kendi muhasebe bürosunda faaliyetini sürdüren bir muhasebeci bazen küçük bir ticaret işletmesi ile birlikte büyük çaplı bir üretim işletmesinin de muhasebe işlemlerini aynı bünyede gerçekleştirmektedirler. $\mathrm{Bu}$ işletmeler birbirinden çok farklı sektörlerde ve ölçeklerde de olabilmektedir. Bu yönüyle muhasebeciler çok sayıda işletmenin muhasebe işlemlerini gerçekleştirdikleri için işletmelerin muhasebeye karşı tutumlarını çok iyi gözlemleme imkanına sahiptirler. Bu bağlamda ekonomik kriz dönemlerinde işletmelerin muhasebeye karşı tutumlarındaki değişiklikleri tespit etme amacını taşıyan çalışmanın hedef kitlesini bağımsız muhasebeciler oluşturmuştur.

Ulaşılabilme imkanı gözetilerek tesadüfi olarak belirlenen illerde yine tesadüfi olarak seçilen yaklaşık 400 muhasebeci ile anket yapılmış ve analize elverişli 361 anket formu elde edilmiştir. Anket formunda işletmelerin kriz dönemlerinde muhasebeye karşı tutumlarındaki değişiklikleri belirlemeye yönelik 12 ifadeye yer verilmiştir. Bu ifadelere verilen cevapların analizi sonucunda öne çıkan önemli bulgular şu şekilde olmuştur.

İlk olarak ankete katılan muhasebecilerin en yüksek derecede "devlete karşı olan sorumluluklarını zamanında yerine getirmek ve cezaya maruz kalmamak için muhasebeye daha fazla önem verirler" ifadesine katılım gösterdikleri tespit edilmiştir. Bu tespit aynı zamanda işletmelerin muhasebeye karşı daha çok yasal zorunluluklarını yerine getirme noktasında bir bakış açısına sahip olduklarını göstermektedir. Benzer şekilde "daha az vergi 
ödemek için muhasebeye daha fazla önem verirler" ifadesinin de en yüksek derecede katılım gösterilen ikinci ifade olması da bu durumu destekler niteliktedir. Ardından "maliyetlerini hesaplama ve azaltmaya yönelik çalışmalara daha fazla önem verirler" ifadesi ise üçüncü en yüksek katılım derecesine sahip ifade olarak tespit edilmiştir.

Diğer taraftan krizden en zararla çıkma ve kriz yönetim stratejilerini belirleme amacıyla muhasebeye daha fazla ilgi gösterme yönündeki ifadelere ise daha düşük düzeyde katılıma yönünde yanıtlar alınmıştır. Bu durum, işletmelerin kriz dönemlerinde muhasebeyi ve muhasebe verilerini çok fazla kriz yönetim stratejisinin bir parçası olarak değerlendirmediklerini ortaya koymaktadır.

Son olarak muhasebecilerin ankette yer alan ifadelere verdikleri cevaplar arasındaki korelasyon araştırıldığında; devlete karşı sorumluluklarını aksatmadan yerine getirme ile daha az veri ödemek için muhasebeye daha fazla önem verme ifadelerine verilen cevaplar arasında istatistiksel olarak anlamlı aynı yönlü korelasyon bulunmaktadır. Benzer şekilde, maliyetleri hesaplama ve azaltma ile işletme sermayesi yönetimine yönelik çalışmalara önem verme arasında da anlamlı bir korelasyon söz konusudur. Ardından krizden en az zararla çıkabilmek için muhasebeye verilen önem ile kriz yönetim stratejilerini belirlemek için muhasebeye daha fazla önem verme arasında da yine anlamlı ve güçlü bir korelasyon bulunmaktadır. $\mathrm{Bu}$ korelasyon sonuçları birbirini tamamlar nitelikteki ifadeler arasındaki anlamlı korelasyonun varlığı ile verilen cevapların tutarlılığını da destekler bir nitelik taşımaktadır.

Sonuç olarak ekonomik kriz dönemlerinde işletmelerin muhasebeye karşı tutumlarında istatistiksel olarak anlamlı bir farklılığın meydana geldiği, bu farklılığın işletmeden işletmeye değişmekle birlikte genel olarak krizi daha iyi yönetmekten ziyade bu dönemde devletle herhangi bir sorun yaşamamak için yasal zorunluluklarını zamanında yerine getirme ve her zamankinden daha az vergi ödeme gayesi doğrultusunda ortaya çıktığı tespit edilmiştir.

\section{KAYNAKLAR}

Akgüç, Öztin (1998), Finansal Yönetim, 6.Baskı, Avcıl Matbaası, İstanbul-1994,

Arıkboğa, Şebnem (2001), "Kriz Ortamında İşletme Yönetimi”, İstanbul: İktisat Dergisi, Şubat-Mart Sayıs1, ss.410-411.

Aysan, Mustafa (2007), "Muhasebe ve Kurumsal Yönetim”, Muhasebe ve Finansman Dergisi, Sayı 35 (Temmuz 2007), ss.17-23.

Birgili, Erhan-Tunahan, Hakan; "Döviz Krizlerinde İşletme Sermayesi Davranış1",http://www.econ.utah.edu/ ehrbar/erc2002/pdf/P103.pdf, (22.04.2012).

Çelik, Aylin, (2003), Fiyatlar Seviyesindeki Değişmelerin Mali Tablolara Etkileri Ve Enflasyon Muhasebesi: Enflasyon Muhasebesi Yöntemlerinden Fiyatlar Genel Seviyesi Modeli Uygulaması, Uzmanlık Yeterlik Tezi. 
Daştan, Abdulkerim (2009), "Ekonomik Kriz Dönemlerinde Muhasebe Bilgi Sisteminin İşletmelerdeki Rolü Ve Kriz Yönetimine Katkısı”, Muhasebe Ve Denetime Bakış, Say1 28 (Nisan 2009), ss.57-72.

Dinç, Engin-Kaya, Uğur (2006), Muhasebe Meslek Mensuplarının "Meslek Ahlak Kuralları" Açısından Hizmet Satın Alanlar Tarafından Algılanma Biçimi Üzerine Bir Araştırma, Muhasebe ve Denetime Bakış Dergisi, Yıl 5, Sayı 17, ss.139-151.

Ekşi, Halil İbrahim (2007), "Finansal Krizlerin KOBİ'ler Üzerindeki Etkileri ve Başarıl1Başarısız KOBİ'lerin Kriz Dönemi Stratejileri”, Yayınlanmamış Doktora Tezi, Süleyman Demirel Üniversitesi, Isparta.

Gücenme, Ümit (2002), “İşletmelerin Finansal Krizden Korunması İçin Bir Önlem: Enflasyon Muhasebesi”, Muhasebe Finansman Dergisi, Ocak 2002, ss. 48.

Kalaycı Şeref. vd., (2009) SPSS Uygulamalı Çok Değişkenli İstatistik Teknikleri, 4.Baskı, Asil Yayın Dağıtım, Ankara.

Karluk, S. Rıdvan-Özgür Tonus-Nazım Çatalbaş (1999), Güneydoğu Asya ve Rusya Krizi Karşısında Türkiye, Marmara Üniversitesi Yayın No: 640 (Prof. Dr. Orhan Oğuz'a Armağan), ss. 259-279.

Kınaytürk, Zuhal (2006), “1990 Yılından Sonra Yaşanan Ekonomik Krizlerin KOBİ'ler Üzerindeki Etkileri”, Yayınlanmamış Yüksek Lisans Tezi, Süleyman Demirel Üniversitesi, Isparta.

Kısakürek, M.Mustafa-Pekcan Ahmet (2005), "Muhasebenin Ürettiği Bilgiye Farklı Açılardan Bakışlar”, C.Ü. İktisadi ve İdari Bilimler Dergisi, Cilt 6, Sayı 2, 2005, ss.107.

Nalbantoğlu, Rıfat (2003), “Muhasebe Uygulamaları Konusunda Meslek Mensuplarının Bakış Açıları ”, VI. Türkiye Muhasebe Denetimi Sempozyumu, 16-20 Nisan 2003,Antalya

Özdevecioğlu, Mahmut (2002), "Krizin İşletmelerin Yönetsel ve Örgütsel Yapısı Üzerindeki Olumsuz Etkileri ve Kayseri Sanayi İşletmelerinde Yapılan Bir Araştırma”, Erciyes Üniversitesi İktisadi ve İdari Bilimler Fakültesi Dergisi, Sayı 19 (Temmuz-Aralık 2002), ss. 93-114.

Özkan, Azzem (2005), "Ekonomik Kriz ve Muhasebe Uygulamalarına Bazı Yansımalar", Hacettepe Üniversitesi, İktisadi ve İdari Bilimler Fakültesi Dergisi”, Sayı 2, ss.165180.

Özkol, A.Erdal-Çelik, Muhsin-Gönen, Seçkin (2005), Kurumsal Sosyal Sorumluluk Kavramı Ve Muhasebenin Sosyal Sorumluluğu, Muhasebe ve Finansman Dergisi Sayı 27, ss.134-145.

Sarıkamış, Cevat (2000), "Ekonomik Kriz Dönemlerinde İsletmelerde Nakit Planlaması”, Muhasebe ve Finansman Dergisi, Say1 5 (Ocak 2000), ss.51-53. 
Seviğ,Veysi (2011), “Kriz Döneminde Yönetim Muhasebesinin Rolü”, http://www.bankaciyiz.biz/koseyazisi/kriz-doneminde-yonetim-muhasebesinin-rolu864.html, (03.12.2011).

Şakrak, Münir (1999), “Kriz Döneminde Muhasebe Bilgi Sisteminin Rolü”, Muhasebe Finansman Dergisi, Say1 10 (Haziran 1999), ss.48-58.

Titiz, İsmet (2003), Kriz Dönemi Yönetsel Kararların Kriz Sonrası İşletme Stratejileri Üzerine Etkisi, S.D.Ü. İktisadi ve İdari Bilimler Fakültesi Dergisi, Cilt 8, Sayı 2, ss.111-123.

Türkiye Odalar Ve Borsalar Birliği (TOBB) (2001), Ekonomik Kriz, Yarattığı Sorunlar ve Çözüm Önerileri (Oda ve Borsalarımızın Görüşleri), Ankara.

Turmob, (2013), Üye İstatistikleri, Meslek Mensubu Dağılım Tablosu (SM-SMMM), http://www.turmob.org.tr/TurmobWeb/Istatistikler.aspx (22.07.2013)

Uslu, Aypar Topkara (1999), "Ekonomik Kriz Dönemlerinde Stratejik Pazarlama Yönetimi ve. Tüketici Davranışları”, Marmara Üniversitesi İktisadi ve İdari Bilimler Fakültesi Dergisi, Y11:1999, Say1 1, ss.465.

Uzay, Şaban-Güngör Şükran (2004), "Muhasebecilerin Sorunları ve Beklentileri: Kayseri ve Nevşehir İlleri Uygulaması", Muhasebe ve Finansman Dergisi, Sayı 22, ss. 94-104.

Yazıcıoğlu, Yahşi-Erdoğan, Samiye (2004), SPSS Uygulamalı Bilimsel Araştırma Yöntemleri, Detay Yayıncılık, Ankara. 
